\title{
4. „ZAGREBAČKE TEME“ U FORMATIVNOM PERIODU SRPSKOG KNJIŽEVNOG GLASNIKA (1920. - 1921.)
}

\section{Gordana Krivokapić Jović}

UDK: 304.2(497.5 Zagreb):821.163.41(051)“1920/21“

Prethodno priopćenje

Sažetak: Identifikovane su i analizirane tzv. zagrebačke teme u Srpskom književnom glasni$k u$ u formativnom periodu njegove nove serije, tokom 1920. i 1921. Analize su smeštene u kontekst šireg znanja o profilu časopisa, odnosno o ličnostima koje su ga osnovale, vodile, o idejama koje su promovisale. U središtu analize su, dakle, kako oni koji su uređivali časopis, tako i oni koji su na njemu sarađivali.

Ključne riječi: Srpski književni glasnik, Bogdan Popović, Milan Begović

\section{SRPSKI KNIIŽEVNI GLASNIK: PROFIL ČASOPISA}

(C rpski književni glasnik $(S K G)$ je bio časopis širokog liberalnog usmerenja, kako u književnosti i umetnosti tako i u političkim pitanjima. Novu seriju časopisa su u jesen 1920. pokrenuli Bogdan Popović i Slobodan Jovanović, a jedno vreme ga i uređivali. ${ }^{1}$ Uz široko postavljen uređivački odbor, smenjivali su se urednici Svetislav Petrović, Miodrag Ibrovac, Milan Bogdanović, Milan Predić i Božidar Kovačević. ${ }^{2}$ Širok krug sarad-

1 Bogdan Popović (1864. - 1944.) je bio univerzitetski profesor od karijere, književni kritičar i esejista, teoretičar i istoričar književnosti. Brat Pavle Popović (1868. - 1939.) je bio profesor univerziteta od karijere, istoričar književnosti i književni kritičar takođe. Obojica su bili akademici, a brat Dimitrije Popović (1866. - 1940.) je bio poznati diplomata i istoričar. Otac Jovan Popović je bio advokat, rodom iz Vukovara. Po majci Savki Marković, oni su bili izdanci srpske zajednice u Zemunu, u graničnom pojasu Monarhije prema Kneževini Srbiji. Deda po majci je bio Stefan Marković, „polkovnik i kavalir“, sekretar kneza Miloša, ugledni političar, više puta ministar, član Društva srpske slovesnosti. Slobodan Jovanović (1869. - 1958.) je bio univerzitetski profesor od karijere, akademik, teoretičar prava i istoričar, političar. Njegov opus dostiže oko 26 studija, monografija, sinteza, iz oblasti istorije i pravnih nauka. Tokom 1939. - 1940. objavljeno je 17 tomova njegovih sabranih dela. I njegovo poreklo je između tzv. južne Ugarske i severne Srbije. Otac, ideolog Liberalne stranke i političar Vladimir Jovanović, a majka Jelena Marinković iz srpske trgovačke porodice iz Novog Sada, gde se Slobodan i rodio.

2 Svetislav Petrović, Miodrag Ibrovac, Milan Bogdanović, Milan Predić, Božidar Kovačević - svi su bili među elitnim književnim kritičarima epohe, ugledni profesori, publicisti, prevodioci i sl. 
nika uključivao je i značajan broj elitnih imena srpske, hrvatske i drugih južnoslovenskih književnosti, kao i naučnog života. Tu objavljuju tekstove: Jovan M. Jovanović (Pižon), Adam Pribićević, Eugen Mautner, Kosta Kumanudi, Bogumil Vošnjak, Slobodan Jovanović, Svetislav Petrović, Miloš Trivunac, Milan Begović, Miloje M. Vasić, Jovan Cvijić, Milan Vlajinac, Isidora Sekulić, Ante Tresić Pavičić, Aleksa Šantić, Dragutin M. Domjanić, Bogdan Popović, Kosta Strajnić, Vladimir Ćorović, Milan Bogdanović, Svetozar Matić, Branislav Miljković, Sibe Miličić, Mileta Jakšić, Mirko Korolija, Dimitrije Popović, Marko Car, Mihajlo Petrović, Milan Grol, Pavle Stevanović, Vladeta Popović, Gustav Krklec, Tihomir Đorđević, Ivo Ćipiko, Vladimir Rejmont, Vladimir Šifer, Miloš Crnjanski, Ivo Andrić, Pavle Popović, Veljko Petrović, Vladimir Nazor, Miloje Milojević, Fedor Nikić, Anica Savić Rebac, Ante I. Cetineo itd. Bio je tu i mali, ali otmeni izbor stranih pesnika i pisaca.

I po poreklu, i po obrazovanju, i po ličnom naboju u spoju sa glavnom tendencijom vremena, to je bio jedan jugoslovenski intelektualni, naučni i kulturno-umetnički melanž. Tu su bili od značajnih naučničkih imena sa težinom antropogeograf Jovan Cvijić, koji je kroz formativni period časopisa dao niz analitičkih tekstova o pitanjima i problemima granica jugoslovenske države u nastajanju; zatim Slobodan Jovanović, koji je dao niz pravnih analiza predloga uređenja nove države; istoričar Vladimir Ćorović, matematičar Mihailo Petrović Alas, istoričar i antropogeograf Tihomir R. Đorđević, i etnolozi Sima Trojanović i Jovan Erdeljanović.

Jovan M. Jovanović Pižon je iz broja u broj objavljivao male brilijantne kritičke studije, beleške i prikaze o spoljnoj politici, međunarodnim odnosima uopšte; Milan Ž. Vlajinac o agrarnoj reformi, a Nikola Stanarević o finansijskoj i trgovačkoj politici. Analize unutrašnjih političkih prilika redovno su davali Kosta Kumanudi i Milan Gavrilović. Uz iskusnog profesora ili političara uvek je išao talentovani učenik. Miloje Milojević je davao priloge iz muzikologije, Kosta Strajnić o arhitekturi (esej o Josipu Plečniku), M. Vasić o arheologiji, sve u novom jugoslovenskom kontekstu.

Pozorišne kritike i preglede su pisala već ugledna imena: Milan Grol, Milan Begović, Uroš Džonić, Branimir Livadić, Borivoje Jevtić. I onda se tu ređala plejada književnih kritičara od formata. Pored braće Popović, tu su bili Miloš Trivunac, Miodrag Ibrovac, Vojislav M. Jovanović Marambo, Branko Lazarević, Marko Car i Arsen Vencelides. Od književnih imena u $S K G$-u počinju da objavljuju buduća najveća imena jugoslovenske književnosti, ali pored mladih tu su i stari: Aleksa Šantić, Jovan Dučić, Milutin Bojić, Miloš Crnjanski, Ivo Andrić, Dragiša Vasić, Milan Kašanin, Rastko Petrović i Momčilo Nastasijević. Iz hrvatskih sredina dolaze Vladimir Nazor, Ante Tresić Pavičić, Gustav Krklec, Augustin Tin Ujević, Mirko Korolija i Josip Kosor.

Dominirala su imena srpske i hrvatske moderne, kao i predstavnici novih pravaca. Arsen Vencelides, prikazujući roman Milana Begovića Dunja u kovčegu, govori o anacionalnosti pokreta „hrvatske moderne“. On veli kako „...Pristaše moderne htjeli su praktično dokazati da narodna književnost može biti i bez nacionalističkoga sadržaja ili smjera (što je drugdje bilo odavno van spora), ali udariše u drugu krajnost, u naročito izbjegavanje svega što je narodno.“3 Vencelides misli da je to naročito naškodilo Begoviću, i pozdravlja njegov po-

Arsen Vencelides [Arsen Wencelides], „Milan Begović, „Dunja u kovčegu“, Srpski književni glasnik, n. s., IV/(16. oktobar) 1921., br. 4, 309-311. (ćir.) 
vratak „narodnim temama“ kroz Dunju u kovčegu, gde se radnja događa između Zagore, Kvarnera i Beča. Prikaz Dalmatinske zagore, odnosno Cetinske krajine (uzduž reke Cetine, sa Dinarskim planinama na vidiku), u trouglu Knin, Drnišs, Sinj, gde se nalazi i piščevo rodno mesto Vrlika, je prostor sa koga dolaze Ivan Meštrović, Dinko Šimunović, Mirko Korolija... to je srce šireg prostora odakle su s jugoistočne strane Tin Ujević, a sa severozapadne Vladan Desnica. Ambijent raskošne lepote, ali i učmalosti i melanholije, čiji su kamen, toplotu, zvuke i mirise ovi jugoslovenski velikani ovekovečili kroz svoju umetnost. Begović za Vrliku veli da je „malo nepismeno gnijezdo“ gde se ljudi višega i nemirnoga duha nelako osećaju „među lihvarima i političarima, kartašima i pravdadžijama." Pitamo se nije li ovo bila podloga za Begovićevu beskompromisnu otvorenost prema novim sredinama, kroz nova stremljenja? Svi su objavljivali u $S K G$-u.

Programsko opredeljenje nove serije je predstavljalo nastavak predratnih opredeljenja, od pre Velikog rata. Temeljna ideja koju su promovisali u političkoj ravni je bila ideja Slovenskog juga, po kojoj taj prostor pripada narodima koji ga naseljavaju. $S K G$ je široko poslužio jugoslovenskoj misli, a njegov znameniti urednik Jovan Skerlić je bio najrečitiji, najznatniji zagovornik toga. Međutim, dok je pre Velikoga rata njegov glas odjekivao na južnoslovenskom prostoru, dotle se u novostvorenoj državi utapao u kakofoniju mnogih glasova.

Ako su u političkoj ravni zastupali liberalizam Džona Stjuarta Mila i donekle Herberta Spensera, otkriven i preveden u prethodnim decenijama, onda su na širem planu odnegovali individualizam, koji je stvar načina razmišljanja i osećanja, pa otuda i uverenja, i stoga nije prevashodno vezan za jednu oblast života. ${ }^{4}$ Tako možemo govoriti o individualizmu u književnoj i teorijskoj misli, u ravni političkih ustanova i političke kulture, u ravni običaja, naravi i vladajućeg morala. U krugu onih koji su vodili $S K G$ skovan je pojam „književni liberalizam“ i odnegovana „kritička misao“ u srpskoj kulturi uopšte, pa i u političkoj kulturi. Bogdan Popović i Skerlić su smatrali da samo „slobodna rasprava“ vodi do istine. "Gde se govori, gde se probudi interes, tu se istina otkrije, i ljudi nauče tražiti istinu“, veli Bogdan Popović. ${ }^{5}$ Shvatanja koja se često svode na obično precenjivanje sopstvene književnosti i kulture proistekla su iz onoga što B. Popović zove „šovinističkom samoobmanom“, jer „patriotizam je uvek skopčan sa žrtvama, a šovinizam uvek godi sujeti..."

U novoj seriji $S K G$-a jugoslovenske teme se konstituišu u svim segmentima, od književnosti do književne kritike, ali i književne politike, preko pozorišne scene i pozorišne politike (znači kulturne politike) širom nove države u nastajanju, do političkih tema. Ustvari radi se o fenomenu prelivanja srodnih užih nacionalnih (ili lokalnih po Miloju M. Vasiću) kultura u novu celinu. Manje su brojne i upadljive društvene i ekonomske teme. U prvim godinama posle rata, da kažemo u prvoj fazi izlaženja časopisa, kritički i polemički tonovi u člancima su prisutni, ali vrlo odmereni (što je odgovaralo kultivisanoj kritičkoj misli koju je $S K G$ odnegovao u predhodnoj fazi), i redakcijska politika je najviše usmerena na percepciju, odnosno viđenje i razumevanje jugoslovenskog prostora, na kvalitetne analize

Leon KoJen, U traženju novog. Individualizam i liberalni duh u srpskoj kulturi (1894-1914), Beograd 1915. (ćir.) Isto, 96.

Bogdan Popović, „Književni listovi“, Srpski književni glasnik, I/(1. februar) 1901., br. 1, 23-36. (ćir.) 
i razrade velikih i važnih tema i sadržaja, onih koje su zahtevale da se nad njima razmišlja, a ne da se na njih samo reaguje. Dakle, za časopis su to bile godine upoznavanja jugoslovenskog prostora.

Hrvatska i „hrvatske teme“ su, može se slobodno reći, bile u središtu interesovanja i usmerenja redakcijske politike, a Zagreb se video kao nepoznanica, naročito posle iskustva Prvog svetskog rata. Ograničeno, ali kvalitetno je praćen rad hrvatskih poslanika (i posebno onih koji dolaze i predstavljaju zagrebačku političku scenu) u Privremenom narodnom predstavništvu, ali to je praktično bilo post festum. Kako su ti političari bivali u Beogradu, i nastupali na ovaj ili onaj način na političkoj sceni, bili su u krugu percepcije i analitičkih tekstova najznačajnijih saradnika časopisa za političke teme.

Redakcija nije imala pravih saradnika, ili bolje rečeno, bila je u potrazi za pravim saradnicima liberalnog usmerenja iz Hrvatske. Među takvima su predstavnici Hrvata viđeni kao apsolutno poželjniji od predstavnika drugih zajednica sa tih prostora. Iz liberalne perspektive nije bilo iznenađujuće da se upadljivo zaobilaze tzv. predstavnici Srba iz Hrvatske, čak i jedan Adam Pribićević (iako se njegovo mišljenje poštovalo, kao i ono njegovog brata Milana). U liberalnim krugovima Beograda i Srbije, i naročito u liberalnom krilu Narodne radikalne stranke, kome je na neki način pripadao i npr. Slobodan Jovanović, predstavnici srpskih zajednica iz Bosne i Hercegovine, kao i iz Hrvatske, nisu viđeni kao dobar „most“ prema drugim zajednicama. Očevidno se nije želelo da se opterećenja prošlosti i mračna događanja iz Velikog rata prenesu na sadašnjost. Ne nacionalno, nego nacionalizmi u sukobu nisu viđeni, nisu bili ono što se želelo za budućnost nove zajednice. Iskustva Prvog svetskog rata, u svim varijetetima, su bila ostavljena nauci, umetnosti, kulturi uopšte, a ne politici.

List se profilisao kroz nekoliko krugova velikih tema, koje je da kažemo odnegovao i kultivisao tokom prve dekade nove posleratne serije, izlazeći dva puta mesečno. Od velikih državno-političkih tema pratio je pitanje granica nove jugoslovenske države i tu gotovo da nije bilo kritičkih tonova, već više kritičkih vapaja prema saveznicima iz rata. „Slovenačke granice“ i ,jadransko pitanje“ bile su opsesivne teme među srpskom političkom elitom i puno mastila je potrošeno na njih i na stranicama $S K G$-a; zatim je tu bilo pitanje državnog uređenja oko koga je postojalo veliko nerazumevanje i otvoreni sukob između hrvatske i srpske političke elite. Za njega je vezano i objavljivanje jednog od najuticajnijih analitičkih tekstova ondašnjeg vremena „Je li federalizam kod nas moguć" Slobodana Jovanovića.?

\section{Prva percepcija Zagreba i Radićev pokret}

Kroz velika pitanja agrarne reforme i prateće situacije uznemirenosti u agrarnim zajednicama, naročito onima koje su okruživale najznačajnija urbana središta, u ovom slučaju Zagreb, percipiraju se i elaboriraju prilike u hrvatskim sredinama i posebno Zagrebu. Vidi

Slobodan Jovanović, „Je li federalizam kod nas moguć?“, Srpski književni glasnik, I/(15. novembar) 1920., br. 6, 435-441. (ćir.) 
se jasno da Radićev pokret još nema ozbiljnijeg uporišta u Zagrebu, ali da je u neposrednom agrarnom okruženju snažan. Nejasno im je da li su događanja iz 1920. u ovom prstenu oko grada partijski organizovana, ili spontana, ili inspirisana raznorodnim idejama, ili je nešto drugo u pitanju. To je dovelo do objavljivanja nekoliko divergentnih članaka, koji su različito videli okolnosti, sama događanja, ljude u njima, različito razumevali i zaključivali.

Prvi članak o Hrvatskoj uopšte, i posredno i neposredno o Zagrebu, pojavio se u br. 3 $S K G$-a od 1. oktobra 1920. iz pera Adama Pribićevića, a pod naslovom „Seljački nemiri u Hrvatskoj“" ${ }^{8}$ On govori da je prostor seljačkih nemira u Hrvatskoj (Sisak, Velika Gorica, Dugo Selo, Križevci, Koprivnica, Bjelovar, Križ, Čazma, Sveti Ivan Zelina) „kula hrvatske opozicije poslednjih 20 godina“ i da je njegova glavna parola „vjera u Boga i seljačku slogu“. On veli da uzroci seljačkih nemira nisu socijalno-politički ili ekonomsko politički, i to poredi sa daleko siromašnijim srezovima koji su u drugom pravcu politički orijentisani. Razlikuje niz uzroka opšteg, svetskog karaktera kao što je revolucionarna psihoza sa ruskim žarištem, teška ekonomska situacija, poremećaj moralne ravnoteže u ljudstvu, pad prestiža vlasti države. Kao uzroke sekundarne naravi vidi apriorno neprijateljsko držanje prema vlasti i tuđinsku agitaciju, mađarsku i italijansku.

$\mathrm{U}$ istom broju $S K G$ je objavio i tekst poznatog zagrebačkog novinara, u tom trenutku urednika Trgovinskog lista, Eugena Mautnera, na istu temu. ${ }^{9}$ I on vidi širi i uži aspekt tih seljačkih nemira. Govori o „revolucionarnoj neurozi... kojoj se ni naše selo nije moglo oteti, jer se sve mase u Europi nalaze u jednom bolesnom stanju...". Zatim govori o „nekažnjeno sprovođenoj akciji tuđinskih agenata spolja i separatističkih elemenata iznutra" kojima je bio cilj da razruše državno jedinstvo, i kao treće naglašava da su „nemiri obojadisani i šovinističkim duhom" i izraz su plemenske mržnje i netrpeljivosti. Njegove najopštije opservacije odnose se na opadanje autoriteta vlasti povezano sa nedostatkom kontinuiteta vlasti. U tom pravcu on kaže da „o masama seljačkim niko ne vodi računa i one su ostavljene same sebi i svima rđavim instinktima“, a „mlađa inteligencija (posle se vidi i zagrebačka i provincijalna) igra u Hrvatskoj ulogu ironičnog posmatrača“. On daje jedno solidno poređenje položaja Kraljevine Srba, Hrvata i Slovenaca sa ostalim državama nastalim posle raspada Habzburške Monarhije.

Sledeći jedan od svojih osnovnih stavova da slobodna rasprava vodi do istine, $S K G$ u sledećem broju od 16. oktobra 1920. donosi tekst Koste Kumanudija „Seljački pokret u Hrvatskoj pred parlamentom“, koji je napisan 10. oktobra 1920. To je zapravo analiza diskusije u Privremenom narodnom predstavništvu o tzv. nemirima u Hrvatskoj. Po njemu, jedni su dokazivali da je buna bila pripremana, drugi da je bila spontana, jedni da je „pokret nosio čisto socijalni karakter“ i imao obeležja klasne borbe, a drugi da je imao „...plemenski značaj sa svim znacima nacionalne netrpeljivosti“. Jedni su govorili da je to bila „planinska bujica koja je silno izbila i brzo prošla“, a drugi da je to bila „eksplozija nezadovoljstva du-

8 Adam PribićEvić, „Seljački nemiri u Hrvatskoj“, Srpski književni glasnik, I/(1. oktobar) 1921., br. 3, 204-210. (ćir.)

9 Eugen Mautner, „Seljački nemiri u Hrvatskoj“, Srpski književni glasnik, I/(1. oktobar) 1921., br. 3, 231-235 (ćir.). O Eugenu Mautneru v. izvrsnu biografsku skicu: „Mautner, Eugen (Mihajlovski, Evgenije)“, Židovski biografski leksikon (http://zbl.lzmk.hr/?p=1252). 
go gomilana i podbadana 'mračnim silama'“, posle čega je dao analizu govora dr Svetozara Ritiga, glavnog govornika Narodnog kluba.

Posle ovog izvrsnog trostrukog sučeljavanja mišljenja o eksplozivnoj situaciji u zagrebačkom okruženju, $S K G$ donosi nešto kasnije još jednu značajnu polemiku na liniji Hrvata i Srba u Hrvatskoj, a odnosi se na njihove odnose prevashodno u Zagrebu i okolini, šire u Zagrebačkoj županiji. Pošto je Vidovdanski ustav bio izglasan u junu 1921. i leto prošlo u pripremama za prvu ozbiljnu reorganizaciju države na novim principima, iz Zagreba se na stranicama $S K G$-a javio Tomislav Tomljenović, koji je oko pola godine, do 28. juna 1921., bio na dužnosti hrvatskog bana. ${ }^{10}$ On je bio poslednji koji je nosio tu titulu. U svom „Pismu iz Hrvatske" daje jednu sveobuhvatnu kritiku stanja na hrvatskim teritorijama i šire u državi. Veli da je vera u zakon, vlast i poštenu državnu politiku uzdrmana u Hrvatskoj. Izražava nadu „...da će se u našoj državi meriti jednakom merom svakom delu naroda $\mathrm{i}$ svakom kraju...". On vidi koterijsku politiku koja radi na račun celine, iako svaka stranka naglašava jednakost i pravdu kao svoja načela (jer „stranke se inače grupišu po velikim načelima“, kako kaže Tomljenović). Poluotvoreno sugeriše da su se stranke sakrile iza velikih načela, ali da su se iznutra rastočile na struje i koterije. Kako je opšti razvoj prilika krenuo put borbenog plemenskog stava, vešta i kompaktna manjina u strankama vlada nad većinom i sprovodi svoju politiku. Ta manjina se poziva, veli on dalje, na ispravno stranačko načelo, pa se onda postavi preteška dijagnoza slučaja, a pozivom na bitni državni interes traže izuzetne privremene mere. Tu se otvara polje za neskrupulozne političare, zaključuje Tomljenović. Glavni smisao ovoga „krijumčarenja“, kako on kaže, je da se dovedu na površinu „svoji ljudi“, uglavnom ekstremni spremni da slepo slušaju. Njegov je opšti stav da „bez izgrađene ideologije ne može ni parlamentarna grupa a kamoli stranka, da valjano izvrši svoju misiju“. A po njemu „niti parlamentarna niti demokratska zajednica nisu imale jasne ideologije“, što je otvorilo put krajnjim elementima, koji su u tom metežu imali idealnu priliku da celu grupu odvedu svojim putem. On ističe da je to za vreme „režima g. Protića“ učinio Hrvatski blok/Hrvatska zajednica, a za vreme g. Pašića ,jedan deo Srba prečana sa nekoliko Hrvata predanim im pošto poto“.

Tomljenović je oslikao Hrvatsku zajednicu krajnje negativno. Kaže da je za vreme Stojana Protića ona „doigrala svoju misiju do kraja i naterala, uz pomoć zgodnih prilika i raznih rastrojnih elemenata, veći deo Hrvata na posve plemenski borbeni stav“. Ta stranka je, nastavlja, pri tom „gotovo posve nestala“, ali je ostao „onaj deo žučljive inteligencije“ koji je bio glavni inspirator tog pravca. Ta inteligencija je bila zadojena plemenskom mržnjom i nije bila vaspitana, kako on kaže, u ideji jedinstva, i nastavlja da bude „onaj kvasac koji ne prestaje da podgrejava borbenost protiv državnog jedinstva, makar i po cenu nelegalne borbe“. Za to je primer zbor u Osijeku, „protiv vojske i državnih nameta"11.

U svom diskursu Tomljenović veli da je nasuprot hrvatskom „plemenskom borbenom stavu“ stajao „onaj deo Srba prečana kojemu je usađena mržnja na Hrvatstvo i Zagreb... i

\footnotetext{
$\overline{10}$ Tomislav TomLjenović, „Pismo iz Hrvatske“, Srpski književni glasnik, n. s., IV/(16. septembar) 1921., br. 2, 149-153. (ćir.)

11 Isto, 150-151.
} 
koja je za narodno jedinstvo tek prividno, samo iz oportuniteta...“. Ona traži „zavojevački pravni akt za svoje srbovanje... postupa opreznije... grabi sve državne poslove u svoje ruke... da se na svakom koraku osete oni i njihovi.... On kaže da „svako joj je frankovac i izdajnik države ko joj je na putu, ili ko ne pleše po njenoj svirci“. ${ }^{12}$

Ima nekih finesa u ovoj poraznoj slici političkih prilika u Hrvatskoj i Slavoniji, u kojoj su vladale „borbene plemenske struje“, „koterijske struje“, koje su otvarale put ličnom režimu, gde je inteligencija upadala u te koterijske struje i ekstremni pravac koji je vođa promovisao. U tu struju su upali mnogi Srbi koji su npr. nekada bili „otvoreni Jugosloveni“. Tomljenović je mislio da je ekstremizam zahvatio većinu Hrvata, ali da „hegemonija i imperijalizam" nisu zahvatili većinu Srba. Uzajamno su se te dve borbe ekstremne struje nadopunjavale i zajednički podgrizale narodno jedinstvo. Tomljenović navodi više tačaka na kojima se videla sličnost u taktici te dve struje: prvo, obe su htele da isključe svaki upliv „Srbijanaca“ iz hrvatskih poslova, i time bansku vlast u Hrvatskoj i Slavoniji stavljale između dva ekstrema; drugo, nasuprot Radićevim većima, postala su „Seljačka veća“; treće, obe struje stoje na gledištu da je inteligencija nepotrebna u političkom životu i da je dovoljna nekolicina vođa iz redova inteligencije (sve ostale mandate trebalo je razdeliti među ljude iz neukog puka „koji je navikao da slepo sluša“); četvrto, obe struje neprestano i sistematski raspiruju plemensku mržnju. Dakle, u vreme izgrađivanja države, uzdigli su se demagozi pred neprosvećenom i fanatizovanom masom, od strane inteligencije u predhodnoj fazi, takođe zadojene ekstremizmima svake vrste.

U pozadini je stajalo zalaganje Tomislava Tomljenovića, da se očuva celovitost Zagrebačke županije, koja bi postala u novom državnom organizovanju Zagrebačka oblast. On ju je smatrao u svim pravcima i na svim ravnim jednom celinom, koju je naseljavalo 630.000 stanovnika, i koju je trebalo sačuvati kao takvu, sprečiti, kako je on govorio „neprirodne amputacije“. To je ono što je on smatrao „zavojevačkim pravnim aktom za srbovanje“ i odstupanjem od ideala Srpsko-hrvatske koalicije, dakle odstupanjem od liberalnih ideja. ${ }^{13}$

$\mathrm{Na}$ ovakvim situacijama su se lomile liberalne političke snage u novoj jugoslovenskoj državi, i otvaralo se pitanje njihovog odnosa prema starim i novim državnim okvirima i organizovanjima države.

Odgovor Milana Pribićevića u istom br. 2 od 16. septembra 1921. $S K G$-a odnosio se na članak Tomislava Tomljenovića „O prilikama u Hrvatskoj“ koji se pojavio u br. $8 S K G$-a od 16. avgusta 1921. ${ }^{14}$ Tomljenović je tu govorio o „smeloj teoriji da akt od 1. decembra imade samo manifestaciono značenje za ujedinjenje" i da to predstavlja stalan kvasac za razornu akciju protiv dela ujedinjenja, „da se hoće da naturi plemenska hegemonija kada se za novu državu traži jedan stari datum kao pravni temelj“. Dalje, on u tom članku govori da je počela da se poriče ideologija Srpsko-hrvatske koalicije „s one iste strane, kojoj je to najlepša stranica prošlosti, a to se ne čini bez dubljeg razloga." Optužba da se odstupa od

12 Isto, 152-153.

13 Gordana Krivokapić Jović, Srpska narodna samostalna stranka 1903-1914, Zagreb 2000. (ćir.)

14 Milan PribićEvić, „U odbranu seljačkih veća u Hrvatskoj“, Srpski književni glasnik, IV/(16. septembar) 1921., br. 2, 153-156 (ćir.); Verus [Tomislav Tomljenović], „O prilikama u Hrvatskoj“, Srpski književni glasnik, III/(16. avgust) 1921., br. 8, 628-632. (ćir.) 
„ideologije Srpsko-hrvatske koalicije“ imala je jasno značenje da se odstupa od liberalnih načela, bar od onog glavnog načela ravnopravnosti, za koji su se Srbi u Kraljevini Hrvatskoj i Slavoniji borili i delimično izborili kroz Koaliciju. ${ }^{15}$

Tu vidimo da se dogodilo ono čega se Nikola Pašić pribojavao i što je predviđao, počev od leta pa do 1. decembra 1918. On je bio protiv stvaranja drugog centra ujedinjavanja Južnih Slovena kako na međunarodnom tako i na unutrašnjem planu jer je cenio da bi to moglo izazvati sukobe sa lošim završetkom po jugoslovensko ujedinjenje u celini. Ako je na međunarodnom planu izbegnuto stvaranje drugog centra ujedinjavanja, onda je na onom unutrašnjem prvodecembarski akt bio greška po njemu, imajući u vidu srpske interese. On je želeo, naročito posle Ženevske konferencije u novembru 1918., da se tačno definiše obim proširene Srbije, odnosno onih teritorija koje žele da se direktno priključe Srbiji. Govorio je u tradiciji Istočnog pitanja da se Srbija, ujedinjena sa Bosnom i Hercegovinom i Crnom Gorom, posle može ujediniti sa Srbima, Hrvatima i Slovencima Habzburške Monarhije. ${ }^{16}$ To je izazvalo rascep u srpskom državnom vrhu, i navuklo optužbe da je on za velikosrpsko rešenje.

Suština odgovora Milana Pribićevića „Verusu“ (on nije znao pravo ime autora) bila je, da je sporazum između Srba i Hrvata u Hrvatskoj preduslov za sporazum na državnom planu. Branio je „Seljačka veća“ kroz opis karaktera naroda u tim većima, i bez konkretnih činjenica o ponašanju tih veća. On je smatrao da „nacionalno oslobođenje“ treba da bude dopunjeno ekonomskim i kulturno-prosvetnim (otpočeto pre rata), što je našlo izraza u pisanju Srpskog kola, organa Seljačkih veća. Njegova slika tih veća ima crte idealizacije: nema demagoga, nema komunista, neguje se i dalje ljubav prema Srbiji, prema novoj državi, bratsko držanje prema Hrvatima.

\section{ZAGREBAČKA POZORIŠNA SCENA}

Zagrebačka pozorišna scena, kao i kulturna događanja i prilike u umetnosti, bili su neka vrsta zamene za ono što se nije moglo naći u političkim i pratećim intelektualnim krugovima, a vremenom će se naći i na drugim ravnima. Očito je u pozorišno-umetničkim krugovima bilo daleko više liberalnog duha nego bilo gde drugde. $S K G$ je dobio izvrsnog saradnika u liku kontroverznog pisca i kritičara Milana Begovića, i zahvaljujući njemu je postao referentno mesto za upućivanje i u šire društvene prilike u Zagrebu, jer su se one izvrsno oslikavale kroz njegove pozorišne kritike. Begović je i posredno i direktno obaveštavao čitaoce $S K G$-a o idejnim, da kažemo i ideološkim strujanjima u Zagrebu budući da je dobro poznavao „kako ko diše“. Njegovo poznavanje književnih i dramskih trendova, (srednje)evropsko pozorišno i umetničko iskustvo i njegov „modernizam“ (ili „modernost")

15 G. KRIVOKapić Jović, Srpska narodna samostalna stranka.

16 Ista [G. KrivoKapić], „Francusko viđenje unutrašnje politike Kraljevine Srba, Hrvata i Slovenaca u vreme njenog konstituisanja 1918-1921“, u: Naučni skup Jugoslovensko-francuski odnosi: povodom 150 godina od otvaranja prvog francuskog konzulata u Srbiji (ur. Slavenko Terzić), Beograd 1990., 248-257. (ćir.) 
učinili su ga u tim godinama vrlo prilježnim, otvorenim i za nova jugoslovenska stremljenja u kulturi i umetnosti, i pored toga što je umeo da ispolji i ličnu osetljivost.

Intelektualno prijateljski serkl kome je pripadao, pre svih Miroslav Krleža i Ljubo Babić, ali i čitava četa elitnog pozorišnog sveta koji je poznavao (Branko Gavella, Vladimir Stanimirović, dr Nikola Andrić, Tomislav Krizman, Mirko Korolija, Dubravko Dujšin, Vika Podgorska, Vladimir Nazor, Marko Soljačić), postao je vidljiv beogradskoj sredini. On je poznavao, ali i imao mišljenje, o svim aktuelnim režiserima na svim zagrebačkim scenama, o glumcima i pre svega o dramskim tekstovima i libretima. Njegov živahan temperament, otvorenost, sposobnost da hvali uz oduševljavanje i kritikuje sa argumentima, sposobnost da kroz pozorišne kritike govori o širokoj lepezi tema, da daje tumačenja dramskih tekstova i predstava, njegovo novo tumačenje istorije, bili su vrlo uklopljivi u tradicionalno vrlo „otvoren“ časopis, što je negovano i u ovoj fazi. Pojedinačno lično introvertnom, ali zato intelektualno otvorenom i prilagodljivom intelektualnom-naučnom krugu koji je okupljao $S K G$, odgovarao je i prijao kriticizam koji je Begović negovao. Na razvoju individualne svesti i kritičkog mišljenja u više ravni, on je uostalom i nikao. Tako je pre-rafaelitizam u liku i delu Milana Begovića stigao na stranice $S K G$-a i beogradska intelektualna sredina mogla je da prati mapiranje hrvatske kulture u vremenu i prostoru i početak uzdizanja Krleže na mesto autoriteta u kulturi, onoga koji je ovlašćen da predstavlja i identifikuje hrvatsku kulturu. Interakcija literature i vizuelnog bila je sjajno oličena u postavkama npr. Krleže i Begovića gde su scensku postavku radili npr. Tomislav Krizman ili Ljubo Babić, a režiju npr. Branko Gavella. Tako je na iznenađujući i efektan način $S K G$ aktuelizovao „zagrebačke teme" na beogradskoj kulturnoj sceni.

Milan Begović je tokom celog perioda izlaženja $S K G$-a u novoj seriji, tokom i 1920-ih i 1930-ih godina, objavio 28 tekstova, manjih ili većih pozorišnih kritika zagrebačkih predstava, koje su sadržale često i manje dopune o drugim događanjima vezanim za pozorište. Prva, pod jednostavnim naslovom „Zagrebačko pozorište“, pojavila se u br. 5 od 1. novembra 1920., a poslednji prilog dao je za br. 6-7 od 16. jula do 1. avgusta 1938. pod naslovom „Tri čovjeka u mom životu. /Rihard/ Demel - Luiđi Pirandelo-Rakić“" ${ }^{17}$ Bez obzira na sve preokrete, skandale i kontroverze koje su ga pratile u nastupanju u javnom životu, na pozitivne ili negativne kritike njegovih dela na stranicama $S K G$-a, njemu je časopis ostao otvoren za objavljivanje, $\mathrm{i}$ on je ostao veran časopisu.

Begović je u br. 7 (knj. I) od 1. decembra 1920., u svom drugom prilogu u $S K G$-u, objavio opsežan tekst o drami Mirka Korolije Zidanje Skadra, za koju je autor uskoro dobio Demetrovu nagradu. U vrlo nadahnutom i afirmativnom tekstu, on „dramu ljepe i mlade Gojkovice“ tumači kao dramu „čitave naše Nacije“, i naravno kao dramu lepote. I glavni i sporedni likovi viđeni su kao posebni simboli: tri brata Mrnjavčevića, koji grade grad na Bojani viđena su kao „naša tri plemena, koja zidaju idealni grad našeg ujedinjenja“, žrtvo-

17 V. Staniša Vojınović, Srpski književni glasnik 1920-1941. Bibliografija nove serije, Beograd 2005., 660 (ćir.) (Registar imena sadrži popis svih njegovih tekstova pod brojevima javljanja; tekstovi o kojima je reč se nalaze pod br. 111 i 10946.); Digitalna Narodna biblioteka Srbije (http://digitalna.nb.rs/sf/NBS/casopisi_pretrazivi_po_datumu/Srpski_knjizevni_glasnik) poseduje digitalizovanu verziju časopisa $S K G$ u kompletu. 
vanje „mlade Gojkovice“ je žrtvovanje Srbije itd. Simbolika je izvedena do kraja, „do čitave i jedinstvene drame našeg Naroda." ${ }^{18}$

U trećem svom prilogu $S K G$-a u br. 4 (knj. II) od 16. februara 1921. on daje prikaz tri predstave iz zagrebačkog pozorišnog repertoara: Slijepci Danka Anđelinovića i Požar strasti i Nepobjediva lada od Josipa Kosora. Kritičan je u njihovom prikazivanju, uz finu opasku da u Slijepcima ipak ima nešto, jer je to priča o „fizički slijepom sinu i moralno slijepom ocu“. Veli da je to „....jedna slika iz hrvatskog prevrata 28. oktobra 1918. Naoko izgleda ova stvarca kao patriotički izljev oduševljenog Jugoslovenina, ali ko pažljivije promotri njezinu suštinu naći će se pred jednim problemom koji je sigurno obuzeo dušu mnogog našeg čovjeka u teškim danima svjetskoga rata i muka i patnja našega naroda. ${ }^{119}$

U sledećim fazama izlaženja $S K G$ je otvorio i niz novih tema sa novim saradnicima, no ova post-ratna faza je bila vrlo značajna i u njoj postavljeno temeljno liberalno pitanje upućeno zagrebačkoj političkoj sceni, a to je zašto Zagreb želi da uredi novu južnoslovensku državu prema principima koji su praktično bili primenljivi samo za njih. Da li je to bilo osporavanje ili potvrđivanje njegovog liberalnog duha i usmerenja? I drugo, manje ofucano, pitanje granica nacionalnih kultura na jugoslovenskom prostoru i njihovo prelivanje.

SKG se javio na početku 20. veka kao izraz jedne dublje promene koja se dogodila u politici, društvu i kulturi u samoj Srbiji, ali i šire. Narodnjaštvo, folklorizam i romantičarski ideali ustupili su mesto kosmopolitizmu, pozitivističko-scijentističkim idejnim strujanjima $\mathrm{i}$ individualnoj kritičkoj svesti. U to su se vezale i druge ideje, kako stare tako i nove. Miloje M. Vasić je tokom rata 1915. i 1916. u nekim svojim neobjavljenim tekstovima razmišljao o stanju kulture u slovenskim zajednicama. On veli da „Slovenstvo mora stvoriti nove kulturne centre, koliko radi opšteg toliko i radi specijalnog slovenskog interesa. ... Danas postoje lokalno modificirane oblasne kulture, među slovenskim narodima koje su manje ili više samo po imenu slovenske (veli on). Slovenski narodi su bili prinuđeni da prihvate strane kulture ili su im prema svome nahođenju dobrovoljno gravitirali. “20 $S K G$ kroz svoju novu seriju upravo svedoči o usponu dva južnoslovenska kulturna centra, Beograda i Zagreba, koji pored svojih užih nacionalnih boja razvijaju i nove jugoslovenske boje, kroz dinamično prelivanje užih nacionalnih kultura.

No Petar Dobrović je, povodom izložbe Bore Stevanovića i Dragutina Arambašića, pisao o „bezfizionomičnosti naše države i našeg društva“, o tome da ni jedno ni drugo još nije

18 Milan Begović, „Pozorišni pregled. 'Poljska bolnica' od V. Stanimirovića i 'Zidanje Skadra’ od Mirka Korolije“, Srpski književni glasnik, I/(1. decembar) 1920., br. 7, 542-551. (ćir.)

19 Isti, „Zagrebačko kazalište. 'Slijepci' od Danka Anđelinovića i ‘Požar strasti' i 'Nepobjediva lađa’ od Josipa Kosora“, Srpski književni glasnik, II/(16. februar) 1921., br. 4, 303-306 (ćir.). U Srpskom književnom glasniku, II/(16. mart) 1921., br. 6, doneo je kritički prikaz tri Begovićeve male aktovke, male komedije (Biskupova Sinovica, Čičak, Cvijetna Cesta) iz pera Branimira Livadića. (ćir.)

20 Dragoslav SREjović, „Miloje M.Vasić, tvorac srpske arheologije“, Projekat Rastko. Biblioteka srpske kulture na Internetu. Arheologija (https://www.rastko.rs/arheologija/srejovic/dsrejovic-vasic.html). On navodi dva neobjavljena teksta Miloja M. Vasića koja se nalaze u njegovoj zaostavštini u Arhivu Srpske akademije nauka i umetnosti. To su: „Nove slovenske armije“ (iz 1915.) i „Slovenska zajednica“ (iz 1916.). 
dobilo svoju određenu, zaobljenu, izrazitu fizionomiju, a da se „država pokazala nesposobnom da intelektualne i umetničke energije iskoristi kao nosioce svoje državne i nacionalne etike. “21

\section{$\cos$ \\ SERBIAN LITERARY GAZETTE (SRPSKI KNJIŽEVNI GLASNIK) ON ZAGREB IN ITS FORMATIVE PERIOD IN I920 AND I92I}

Summary: While making a content analysis of the Serbian Literary Gazette (Srpski književni glasnik) in its formative period (1920-1921), after its new series was launched, quite a lot of themes related to Zagreb came out of it. They have been contextualized having in mind a profile of the review, personalities who established it and their cultural and political priorities, as well as leading ideas which brought them together. The most productive contributors have been identifies, as well as standpoints they have been advocating in an atmosphere of mutual, Serbo-Craotian misunderstandings and willingness to look for alternative approaches in both directions in order to surpass those misunderstandings.

Key words: Serbian Literary Gazette (Srpski književni glasnik), Bogdan Popović, Milan Begović

\section{$\cos$}

\section{Izvori}

Milan Begović, „Pozorišni pregled. 'Poljska bolnica' od V. Stanimirovića i 'Zidanje Skadra' od Mirka Korolije", Srpski književni glasnik, I/(1. decembar) 1920., br. 7, 542-551. (ćir.)

Milan Begović, „Zagrebačko kazalište. 'Slijepci' od Danka Anđelinovića i 'Požar strasti' i 'Nepobjediva lađa’ od Josipa Kosora“, Srpski književni glasnik, II/(16. februar) 1921., br. 4, 303-306. (ćir.)

Petar Dobrović, „Umetnički pregled. Izložba g. g. Bor. Stevanovića i Drag. Arambašića“, Srpski književni glasnik, n. s., IV/(16. oktobar) 1921., br. 4, 312-314. (ćir.)

Slobodan Jovanović, „Je li federalizam kod nas moguć?“, Srpski književni glasnik, I/(15. novembar) 1920., br. 6, 435-441. (ćir.)

Eugen Mautner, „Seljački nemiri u Hrvatskoj“, Srpski književni glasnik, I/(1. oktobar) 1921., br. 3, 231-235. (ćir.)

Bogdan Popović, „Književni listovi“, Srpski književni glasnik, I/(1. februar) 1901., br. 1, 23-36. (ćir.)

Adam PribićEvić, „Seljački nemiri u Hrvatskoj“, Srpski književni glasnik, I/(1. oktobar) 1921., br. 3, 204-210. (ćir.)

Milan PribićEvić, „U odbranu seljačkih veća u Hrvatskoj“, Srpski književni glasnik, IV/(16. septembar) 1921., br. 2, 153-156. (ćir.)

21 Petar Dobrović, „Umetnički pregled. Izložba g. g. Bor. Stevanovića i Drag. Arambašića“, Srpski književni glasnik, n. s., IV/(16. oktobar) 1921., br. 4, 312-314. (ćir.) 
Tomislav Tomljenović, „Pismo iz Hrvatske“, Srpski književni glasnik, n. s., IV/(16. septembar) 1921., br. 2, 149-153. (ćir.)

Arsen Vencelides [Arsen Wencelides], „Milan Begović, „Dunja u kovčegu“, Srpski književni glasnik, n. s., IV/(16. oktobar) 1921., br. 4, 309-311. (ćir.)

Verus [Tomislav Tomljenović], „O prilikama u Hrvatskoj“, Srpski književni glasnik, III/(16. avgust) 1921., br. 8, 628-632. (ćir.)

\section{Literatura}

Leon Kojen, U traženju novog. Individualizam i liberalni duh u srpskoj kulturi (1894-1914), Beograd 1915. (ćir.)

Gordana Krivokapić, „Francusko viđenje unutrašnje politike Kraljevine Srba, Hrvata i Slovenaca u vreme njenog konstituisanja 1918-1921“, u: Naučni skup Jugoslovensko-francuski odnosi: povodom 150 godina od otvaranja prvog francuskog konzulata u Srbiji (ur. Slavenko Terzić), Beograd 1990., 248-257. (ćir.)

Gordana Krivokapić Jović, Srpska narodna samostalna stranka 1903-1914, Zagreb 2000. (ćir.)

Staniša Vojınović, Srpski književni glasnik 1920-1941. Bibliografija nove serije, Beograd 2005. (ćir.)

\section{Mrežne stranice}

Digitalna Narodna biblioteka Srbije (http://digitalna.nb.rs/sf/NBS/casopisi_pretrazivi_po_datumu/ Srpski_knjizevni_glasnik)

„Mautner, Eugen (Mihajlovski, Evgenije)“, Židovski biografski leksikon (http://zbl.lzmk.hr/?p=1252)

Dragoslav SRejović, „Miloje M. Vasić, tvorac srpske arheologije“, Projekat Rastko. Biblioteka srpske kulture na Internetu. Arheologija (https://www.rastko.rs/arheologija/srejovic/dsrejovic-vasic.html) 